\title{
СУТЬ ТА АСПЕКТИ ЯКОСТІ ОСВІТНЬОГО СЕРЕДОВИЩА ЯК ОСНОВИ ЕФЕКТИВНОЇ ПІДГОТОВКИ ІНОЗЕМНИХ СТУДЕНТІВ ДО НАВЧАННЯ В ТЕХНІЧНОМУ ВНЗ
}

\begin{abstract}
Часова Е. В., Івчук В. В. Суть та аспекти якості освітнього середовища як основи ефективної підготовки іноземних студентів до навчання в технічному ВНЗ.

У статті окреслено суть та деякі аспекти якості освітнього середовища, на основі яких розкрито шляхи ефективної підтримки студентів-іноземців. Наведені можливості допомоги іноземним студентам у процесі їх адаптації в умовах освітнього середовища вищого навчального закладу технічного профілю.
\end{abstract}

Ключові слова: якість освітнього середовища, іноземні студенти, педагогічна підтримка, соціалізація, освіта за кордоном.

Часова Э. В., Ивчук В. В. Суть и аспекты качества образовательной среды как основы эффективной подготовки иностранных студентов к обучению в техническом вузе.

В статье представлены суть и некоторые аспекты качества образовательной среды, на основании которых раскрыты пути эффективной поддержки студентовиностранцев. Приведены возможности помощи иностранным студентам в процессе их адаптации в условиях образовательной среды высшего учебного заведения технического профиля.

Ключевые слова: качество образовательной среды, иностранные студенты, педагогическая поддержка, социализация, образование за рубежом.

Chasova E. V., Ivchuk V. V. Essence and quality aspects of the education as the basis for effective training of international students at higher technical schools.

The article presents some aspects of the quality of education on the basis of which ways of efficient support for international students are suggested. The authors speak about some help for international students in their adaptation process when being educated at higher schools majoring in technology.

Key words: quality of education, international students, pedagogic support, socialization, foreign education.

Глобалізація вищої освіти стала в останнє десятиліття результатом збільшення кількості студентів, які отримують освіту за кордоном. Складності отримання освіти для таких студентів, зумовлені необхідністю входження до нерідного середовища і культури, вивчення нової мови, звикання до особливостей клімату, незнайомої їжі і т.П., актуалізують значущість підтримки іноземних студентів. Водночас, незважаючи на значну кількість розробок проблеми педагогічної підтримки (В. Кабуш, Н. Косицина, Н. Крилова, Н. Михайлова, С. Попова, К. Роджерс, І. Якиманська) і досліджень адаптаційних складнощів іноземних студентів (М. Іванова, Л. Кожуховська, Н. Лебедєва, А. Ременцов, Т. Стефаненко, А. Суригін, Х. Триандис), питання педагогічної підтримки іноземних студентів не були предметом спеціального дослідження [1].

Освітня система на сучасному етапі характеризується такими явищами як переосмислення раніше накопиченого досвіду, пошук нових форм і змісту освіти, які мають відповідати потребам соціуму, а також затвердження сучасного наукового 
апарату педагогіки. Усі ці явища тісно пов'язані з взаємодією у всіх областях сучасного життя. Дослідження взаємодії суб'єктів освітнього процесу, як основи підготовки іноземних студентів до навчання у технічному ВНЗ, становить науковий інтерес не тільки в теоретичному, але і в практичному плані. У світлі гуманістичного спрямування, сучасна педагогіка вищої школи приділяє увагу визначенню ролі викладача і студента в освітньому процесі. Взаємодія, як процес спільної діяльності суб'єктів, на етапі підготовки іноземних студентів до навчання у технічному ВНЗ передбачає активізацію навчально-пізнавальної діяльності іноземного студента у процесі навчання і вимагає від викладача врахування індивідуально-психологічних особливостей студентів. Особистісно зорієнтований підхід в навчанні студентів в процесі педагогічної взаємодії залежить від викладача - його загальної та педагогічної культури, кваліфікації та особистісних якостей. Активна діяльність студента, яка виражається в прагненні до особистісного зростання і творчості, залежить від мотивації і індивідуальних здібностей студента. Незважаючи на велику кількість робіт, присвячених проблемі діяльності суб'єктів в освітньому процесі (Г. Романцев, М. Каган, Е. Коротаєва, І. Котова, Е. Шиянова, Е. Свдокимова та ін.), проблема взаємодії суб'єктів на етапі довузівської підготовки іноземних студентів не знайшла належного відображення в педагогічній літературі [5].

Mema cmammi- розглянути організацію педагогічної підтримки іноземних студентів шляхом застосування можливостей освітнього середовища навчального закладу. Показати взаємодію суб'єктів навчального процесу в навчальних групах задля підвищення ефективності підготовки студентів-іноземців до навчання у технічному вузі.

Проблема створення в навчальному закладі підтримуючого освітнього середовища набуває особливої значущості в актуальності щодо іноземних студентів. Підтримуюче середовище, в цьому випадку, виступає як посередник між середовищем країни навчання і конкретним іноземним студентом, становлячи собою сукупність умов 3 надання допомоги іноземним студентам, 3 яких найбільш значущими $є$ : медико-психологічна допомога; адаптаційна допомога, яка становить запобігання та розв'язання соціокультурних проблем; дидактична допомога, яка полягає в нейтралізації навчально-пізнавальних складностей і оптимізації процесу адаптації до ВН3 і процесу навчання. Підтримуюче середовище ВНЗ реалізує як превентивні (запобігають виникненню складнощів), так і оперативні (безпосереднє реагування на виниклу у студента проблему) напрямки допомоги і дозволяє сформулювати умови ефективності наданої іноземному студенту підтримки. Дослідниками освітнього середовища (Н. Масюкова, В. Ясвин та ін.) були представлені основні параметри та їх характеристики. Для підтримуючого іноземних студентів освітнього середовища значущими параметрами якості $\epsilon$ : модальність, широта, когерентність, усвідомленість, інтенсивність і узагальненість [3].

Модальність $є$ змістовною характеристикою середовища. Для підтримуючого середовища такою змістовною характеристикою $є$ надання допомоги іноземним студентам. Відповідно, параметр модальності визначає як умову 3 реалізації педагогічної підтримки іноземних студентів максимально повне використання можливостей освітнього середовища. Така умова є основною, оскільки параметр широти, що показує загальну спрямованість педагогічного процесу, становить єдиний параметр, який характеризує середовище з позиції якості. Інші параметри, як кількісні характеристики освітнього середовища, допомагають розкрити умови 3 надання педагогічної підтримки іноземним студентам [4]. 
Умова максимально повного використання можливостей освітнього середовища у процесі надання допомоги іноземним студентам висуває низку вимог з організації підтримуючого середовища вузу: врахування особистісних характеристик педагогів при призначенні кураторами та викладачами навчальних груп іноземних студентів; необхідність володіння іноземними мовами педагогами, які взаємодіють 3 іноземцями, що сприяє прискоренню та спрощенню розв'язання їх проблем; організацію спеціальних занять 3 ознайомлення співробітників ВНЗ 3 основами педагогічної підтримки; роботу 3 саморозвитку як педагогів, так і студентівіноземців [3].

Відносно просторово-предметного компонента середовища ВНЗ, найбільш загальними вимогами $\epsilon$ : використання світлих тонів в оформленні приміщень; комфортна температура i достатня освітленість; наявність зручних меблів; естетичність і гармонійність використовуваних предметів інтер'єру; сучасність використовуваної в освітньому процесі навчальної техніки та обладнання; достатність i різноманітність використовуваних у процесі навчання засобів (підручники, словники, методичні та ілюстративні матеріали) [1].

Дидактичний компонент виражає дві різноспрямованих вимоги: забезпечення для новоприбулих іноземців адаптаційного режиму діяльності, а також інтенсифікація оволодіння нерідною мовою та культурою. Створення адаптаційного режиму передбачає: невелику наповнюваність груп; створення комфортної доброзичливої атмосфери на заняттях; поступове нарощування обсягу засвоюваного матеріалу. Вимога інтенсифікувати засвоєння нерідної мови та культури визначає рекомендації щодо організації занять з української або російської мови, як іноземних: засвоєння побутової лексики, поведінки та комунікації в ситуаціях щоденної взаємодії; використання різноманітних, переважно активних форм роботи; уявлення культурних традицій і соціальних норм країни навчання [6].

Використання можливостей освітнього середовища 3 надання допомоги іноземним студентам щодо позанавчального компонента освітнього середовища визначає наступні вимоги: регулярність та інтенсивність організації позанавчальної активності студентів. Це виражається в обов'язковості організації дозвілля студентів і спеціального планування такої діяльності, а також різноманітність проведених заходів [7].

Параметр широти освітнього середовища показує, наскільки широко представлене освітнє середовище, які об'єкти, суб'єкти і процеси в нього включені. Даний параметр для вираження відносин підтримки визначає вимогу щодо розширення сфери дії освітнього середовища. Це виражає необхідність представлення іноземцю середовища вузу, а також максимального розширення його освітнього середовища: ознайомлення 3 прикметами міста, розміщенням необхідних установ i взаємодією 3 ïx співробітниками. Параметр широти також визначає вимогу змістовного розмаїття освітнього середовища: кола осіб, які контактують 3 іноземними студентами, форм і методів навчальної та позанавчальної роботи, використовуваних у навчанні засобів. Відносно соціального компонента параметр широти може бути конкретизований як залучення максимально широкого кола осіб в процес соціалізації іноземних студентів [8].

Основною складністю для іноземних студентів $\epsilon$ факт навчання в нерідному середовищі, що дає можливість визначення значущості в рамках підтримуючого середовища іноземного студента параметра когерентності, який визначає зв'язок освітнього середовища ВНЗ з середовищем існування. Параметр когерентності відносно підтримуючого освітнього середовища виражає необхідність організації 
заходів, спрямованих на нейтралізацію несприятливих впливів нерідного середовища. Окреслена вимога спрямовує роботу 3 іноземними студентами на ознайомлення 3 нерідною країною, особливостями взаємодії з місцевими жителями, національними традиціями і правилами поведінки [1].

Параметр усвідомленості, що характеризує включення в освітнє середовище всіх суб'єктів педагогічного процесу, визначає вимогу до позицій осіб, які приймають участь у процесі соціалізації новоприбулих іноземців. Для успішного функціонування педагогічної підтримки параметр усвідомленості визначає необхідність формування підтримуючої позиції педагога. Позиція педагога знаходить вираз в підтримуючій поведінці, що характеризується його включенням в життя навчальної групи; щирим інтересом до життя студентів; прагненням з'ясувати труднощі студентів, їх причини, спланувати процес надання допомоги; активністю при розв'язанні проблем і відповідальністю; бажанням сформувати активну життєву позицію студентів [2].

Головним елементом будь-якої взаємодії в освітньому процесі є особистість як викладача, так і студента, які є суб'єктами освітнього процесу. Взаємодія суб'єктів освітнього процесу включає: навчально-педагогічну взаємодію студента і викладача; міжособистісну і міжкультурну взаємодію; взаємодію особистості і групи; особистості і середовища; особистості і ситуації [3].

Взаємодія суб'єктів освітнього процесу на етапі довузівської підготовки - це складний, багатофункціональний процес, що визначає спільну активну діяльність суб'єктів 3 метою досягнення позитивного результату. У процесі педагогічної взаємодії, діяльність викладача заснована на особистісно зорієнтованому підході і реалізується через зміст і форму навчальних занять, через характер спілкування зі студентом. Діяльність студента передбачає суб'єктну активність учня, яка виражається у прагненні до особистісного зростання та творчої діяльності. Суб'єкти освітнього процесу характеризуються як загальними, так $\mathrm{i}$ специфічними особливостями. Специфічною особливістю суб'єктів освітнього процесу $\epsilon$ приналежність іноземних студентів і викладачів до різних культур. Іноземні студенти на етапі довишівської підготовки навчаються в навчальних групах, як мононаціональних, так і інтернаціональних, тому педагогічна взаємодія в освітньому процесі передбачає не тільки міжособистісну взаємодію, але i міжкультурну взаємодію суб'єктів освітнього процесу [8].

У психолого-педагогічній літературі виокремлюють основні групи чинників успішності іноземних студентів у процесі взаємодії суб'єктів на етапі довишівської підготовки: психологічна атмосфера в навчальній групі; відносини між викладачем і студентом; діяльність навчальної групи. Втокремлюють групи факторів психологічної атмосфери в навчальній групі за їх змістовною ознакою: перша група - конативна, визначає рівень емоційного настрою окремої особистості і навчальної групи в цілому; друга - група задоволеності, визначає рівень ефективності та задоволеності навчальним процесом у цілому і його компонентами; третя група - гностична, яка вказує на наявність або відсутність інформаційно-пізнавальних, змістовних ознак в навчальному процесі; четверта група - когнітивна, що встановлює рівень комунікативних зв'язків усередині навчальної групи [6].

Чинники взаємовідносин між викладачем і студентом згруповані за трьома компонентами: гностичний компонент характеризує оцінку студентом компетентності викладача, його сприйняття викладача як професіонала, направляючого діяльність студента; емоційний компонент надає уявлення про ставлення студента до викладача в людському плані, наскільки він йому симпатичний або несимпатичний як особистість; поведінковий компонент дає уявлення про особливості спілкування 
викладача зі студентом, про те, наскільки сприятливо або несприятливо складається їхня взаємодія [2].

Комунікативна компетентність іноземних студентів, їх пізнавальна діяльність на етапі довишівської підготовки, формування навичок і вмінь мовленнєвої діяльності в навчальній групі під керівництвом викладача, залежить і від технології організації навчальної взаємодії. Під технологією організації навчального взаємодії розуміють способи і методи організації навчальної взаємодії викладача та навчальної групи, а також управління з боку викладача цією організацією в залежності від педагогічної ситуації. Технологія організації навчальної взаємодії в навчальних групах повинна бути спрямована на переорієнтацію діяльності викладача від інформаційної до інформаційно-організаційної відповідно до мети та завдань навчальної взаємодії на етапі довузівської підготовки. Результатом оптимально організованої навчальної взаємодії $є$ комунікативна компетентність іноземних студентів, яка досягається в умовах сприятливої психологічної атмосфери на заняттях, відносин партнерства, співпраці і співдружності з викладачем і студентами в навчальній групі [8].

На сучасному етапі розвитку суспільства особливої значущості набуває розвиток суб'єктної позиції особистості, що представлено здатністю самостійно справлятися 3 життєвими труднощами, планувати свою діяльність, проектувати модель особистісного розвитку тощо. Параметр усвідомленості дозволяє сформулювати необхідність формування суб'єктної позиції кожного студента-іноземця. Відповідно, у підтримуючому середовищі організовуються спеціальні заходи, спрямовані на формування такої позиції: формування оптимістичного світосприйняття студентів, спрямованості на позитивну комунікацію і взаємодію з оточуючими; використання активних форм роботи на заняттях; розвиток рефлексивних умінь студентів; формування потреби в саморозвитку у студентів-іноземців, їх духовному та фізичному вдосконаленні, самоактуалізації [6].

Параметр інтенсивності, як показник насиченості середовища умовами i можливостями, визначає у підтримуючому середовищі вимогу щодо створення умов для задоволення основних потреб іноземних студентів: задоволення фізіологічних потреб і потреби в безпеці життєдіяльності, задоволення потреби в любові і повазі забезпечується підтримуючою позицією педагогів, створенням сприятливого мікроклімату в групі, підвищенням самооцінки іноземних студентів, реалізацією їх здібностей; задоволення потреби в самоактуалізації особистості, яка передбачає комплекс процесів, спрямованих на максимальне використання ресурсів, наявних в особистості [1].

Останнім 3 визначальних параметрів якості для підтримуючого освітнього середовища $є$ узагальненість, як показник координації всіх суб'єктів освітнього середовища. Узагальненість визначає низку вимог до організації соціального компонента освітнього середовища: розподіл обов'язків учасників процесу соціалізації 3 надання допомоги іноземним студентам; скоординованість їх дій; безперервність діяльності з надання допомоги новоприбулим студентам [3].

Отже, освітнє середовище ВНЗ - це комплекс підтримуючих конкретного іноземного студента умов. Основні параметри якості підтримуючого освітнього середовища (модальність, широта, когерентність, усвідомленість, інтенсивність і узагальненість) висувають вимоги до організації освітнього середовища ВНЗ і визначають умови та норми ефективної педагогічної підтримки іноземних студентів: використання можливостей усього підтримуючого середовища у процесі надання допомоги; розширення територіальної і змістовної характеристик освітнього середовища; організація впливів підтримуючого освітнього середовища, які 
компенсують несприятливі впливи середовища країни навчання; формування підтримуючої позиції педагогів та суб'єктної позиції іноземних студентів; створення в ВНЗ умов для задоволення основних потреб студентів-іноземців; організація системи комплексного психолого-педагогічного супроводу новоприбулих іноземних студентів.

1. Бордовский Г. А. Управление кітература процесса:[монография] / Г. А. Бордовский. - СПб. : Изд-во РГПУ им. А. И. Герцена, 2001. - 359 с. 2. Компетентностный подход в образовании: [коллективная монография] / под ред. В. А. Козырева, А. П. Тряпицыной, Н. Ф. Радионовой. - СПб. : Изд-во РГПУ им. А. И. Герцена, 2001. - 392 с. 3. Мариненко О. П. О педагогической поддержке иностранных студентов на этапе предвузовской подготовки / О. П. Мариненко // Высшая школа. - 2010. - № 1. - С. 133-141. 4. Пак М. С. Тестирование в управлении качеством химического образования: [монография]/ М. С. Пак, М. К. Толетова. - СПб. : Изд-во РГПУ им. А. И. Герцена, 2002. - 79 с. 5. Пак М. С. Гуманитарное обновление химического образования: [учеб.-метод. пособ.] / М. С. Пак, И. А. Орлова. - СПб.: Издательский дом «МИРС», 2010. - 83 с. 6. Смелкова И. Ю. Влияние психологического климата в учебной группе на успешность обучения студентов / М. А. Иванова, И. Ю. Смелкова // Материалы Х Международной научно-методической конференции «Высокие интеллектуальные технологии и качество образования и науки». - СПб. : СПбГПУ, 2003. - С. 167-168. 7. Смелкова И. Ю. Речевая деятельность как результат поэтапного обучения иностранных студентов научному стилю речи / И. Ю. Смелкова, А. В. Долгополов // Материалы международной конференции «Международное сотрудничество в образовании и науке». - СПб. : Изд. Политехнического университета, 2006. - С. 312 313. 8. Смелкова И. Ю. Взаимодействие субъектов образовательного процесса как носителей разных культур/ И. Ю. Смелкова // Научно-технические ведомости СПбГПУ. - 2006. - № 4. - Вып. 46. - С. 128-130. 